\title{
Comparative Study on the Quality and Antibacterial Activity of Spearmint (Mentha spicata) Leaves and Infusion
}

\author{
Emad A. H. Guirguis \\ Department of Food Hygiene, National Nutrition Institute, General Organization of Teaching Hospitals and \\ Institutes, Egypt.
}

\begin{abstract}
In the present study, a comparative investigation between the quality of spearmint leaves and infusion was performed and antibacterial activity against common pathogenic bacteria. Samples (300) represented loose, packed and fresh leaves in addition to their infusions were examined for the microbiological profile and quantitative analyzed for total aflatoxin. Antibacterial activity of spearmint essential oil was determined by disk diffusion method against pathogenic bacteria. Also, moisture content was evaluated. Considering the results obtained, the moisture content was determined as 85, 8.45 and 7.37\% in fresh, loose and packed leaves, respectively. Overall, levels of microbial loads were generally exceeded the acceptable levels according to the Egyptian Standards in spearmint leaves, while no detectable microbial counts were found in infusion samples. Although, loose leaves contained the highest microbial load, the fresh leaves contained the lowest with Total Aerobic Viable Bacteria (TAVB) $\left(5.7 \times 10^{4} \sim 5.5 \times 10^{7} \mathrm{cfu} / \mathrm{g}\right)$, molds and yeasts count $\left(3.5 \times 10^{2} \sim 8.7 \times 10^{3} \mathrm{cfu} / \mathrm{g}\right)$, spore-forming bacteria $\left(9 \times 10^{2} \sim 4.7 \times 10^{4}\right.$

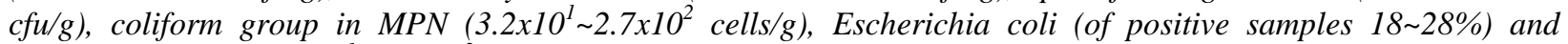
Bacillus cereus $\left(3.6 \times 10^{1} \sim 1.1 \times 10^{2} \mathrm{cfu} / \mathrm{g}\right)$, while Salmonella spp, Shigella spp, Closteridium perfringens and Staphylococcus aureus were not detected. Total aflatoxins $(37.32 \sim 48.73 \mu \mathrm{g} / \mathrm{kg})$ was detected in loose and packed leaves while was not detected $(<5 \mu \mathrm{g} / \mathrm{kg})$ in fresh leaves and infusion samples. The Gram-positive bacterial count seems to be more susceptible to the investigated essential oil, comparing to the Gram-negative ones. Finally, the study pointed out that spearmint leaves consider hazards which urges the need to provide a health control system, and the importance of spearmint essential oil, as an antimicrobial agent.
\end{abstract}

Keywords: Spearmint, Microbiology, Aflatoxins, Antibacterial activity.

\section{Introduction}

Spearmint (Mentha spicata) is specie of mint native to North Africa, Egypt and Morocco. It belongs to the genus Mentha in the family Labiateae (Lamiaceae). It is widely used in commercially manufactured product, cooking and medicine for its aromatic and flavorsome qualities (Sulieman et al., 2011 and Mandana et al., 2011). Leaves of mint plant are frequently used in herbal tea and for culinary purpose to add flavour and aroma. The distinctive smell and flavour, a characteristic feature of Mintha spp. is due to the naturally occurring cyclic terpene alcohol called menthol (Parmila et al., 2012).

The plant genus Mentha contains 25-30 different species and known for its antimicrobial, antiviral and insecticidal activity. Essential oils of mint are extensively used in toiletry, food and pharmaceutical industries because of its aromatic, stimulate and carminative nature (Karicheri and Antony, 2016). There is a relationship between the chemical structure of the most abundant compounds in the essential oil and the antimicrobial activity (Helal et al., 2006).Despite the beneficial effects of herbs, some microorganisms and their metabolites can be found which could lead to serious health problems. Among the microorganisms that may be present, moulds are the most relevant, mainly due to their mycotoxins production capacity. Although the presence of pathogenic microorganisms is relatively rare, there are some exceptions, such as, Bacillus cereus, Clostridum perfringens, Campylobacter jejuni, Escherichia coli, Escherichia vulneris, Enterobacter aerogenes, Enterobacer cloacae, and Pseudomonas aeruginosa. In this kind of commodities production conditions may lead to an increasing risk of microbial contamination. Thus microbial spoilage of the raw herbal material is one of the factors governing the global market of herbs (Santos et al., 2013).

Microbial contamination of plants influenced by environmental factors such as temperature, humidity, extent of rainfall during the pre-harvesting, harvesting, and post-harvesting periods, handling practices and storage conditions of crude and processed medicinal plants materials (Chotchoungchatchai et al., 2012). Aflatoxins (Afs) are difuranocoumarin derivatives synthesized primarily by the fungi Aspergillus flavus, Aspergillus parasiticus and, to a lesser extent, by the Aspergillus nomius (Santini et al., 2015). 
Comparative Study on the Quality And Antibacterial Activity of Spearmint (Mentha Spicata) Leaves and

The growth of fungi that produced Afs in stored commodities is strongly influenced by environmental conditions: in fact high moisture content can increase the Afs amount of 10 fold in 3-day period (Hell et al., 2008). The application of hot water extraction (herbal infusion) usually compensates for microbiological contamination, since it can be expected that boiling water markedly reduces the viable counts by several log units and also inactivates possible pathogens (Mukundi, 2015).

The Egyptian Standard (ES: 2367/2006 and ES: 7136/2010) has proposed to set tolerance levels of dried mint at $10^{4} \mathrm{cfu} / \mathrm{g}$ for the total aerobic viable count and $10^{2} \mathrm{cfu} / \mathrm{g}$ for molds and yeasts count and coliform group count and should be free from pathogenic bacteria. Also total aflatoxins should not exceed $10 \mu \mathrm{g} / \mathrm{kg}$. A general poor microbiological quality of spices and herbs especially those sold as loose in the open air markets. Spices and herbs owe their safety to their low moisture content, but once they get in contact with water-rich food products, microbial populations could develop quickly due to the increasing in water activity (Debs-Louka et al., 2013). The aim of this study was to investigate the microbial, total aflatoxins and moisture comparison between spearmint leaves and infusions. Furthermore, study the effect of its essential oil against some pathogenic bacteria.

\subsection{Sampling}

\section{Materials \& Methods}

A grand total of 300 random samples represented by spearmint leaves included fresh, dry loose and packed forms and there infusions (50 samples of each) were collected from retile markets in Cairo governorate, Egypt. Each sample was kept in a separate sterile plastic bag and preserved in an ice box then transferred to the laboratory under complete aseptic conditions without undue delay and examined as quickly as possible. The infusions were prepared by soaking $1.5 \mathrm{~g}$ of the samples in $200 \mathrm{ml}$ boiled water (Al-Sohaibani $\boldsymbol{e t ~ a l . , ~ 2 0 1 1 ) . ~ T h e ~ s a m p l e s ~ w e r e ~ s u b j e c t e d ~ t o ~}$ moisture content, microbiological and aflatoxin analysis as well as the antibacterial property of its essential oils.

\subsection{Moisture content}

Moisture content of peppermint leaves determined by drying the samples in air forced draft oven (Delab, Mod.: HST-5062, Germany) at $105 \pm 5^{\circ} \mathrm{C}$ till constant weight achieved according to AOAC (2006).

\subsection{Microbiological analysis}

Twenty-five grams of the sample were aseptically weighed in sterile stomacher bags, diluted with $225 \mathrm{ml}$ peptone water, homogenized in a stomacher for $2 \mathrm{~min}\left(10^{-1}\right.$ dilution) and serially diluted in $9 \mathrm{ml}$ of peptone water (Soriano et al., 2002). Microbiological analysis was performed according to the procedures recommended by the International Commission on Microbiological Specification for Foods (ICMSF, 1978 and 1996), (Harrigan, 1998) and (ISO, 2013). Samples were examined to determine Total viable bacterial cout, molds and yeasts count, $B$. cereus, Staph. aureus, coliform group, E. coli, L. monocytogenes, Salmonella spp., Shigella spp., spore-forming bacterial count and $\mathrm{Cl}$. perfringens. The respective media were used in dehydrated forms (Oxoid, Difco and LAB$M)$ in which preparation of media were performed and incubated following the individual instructions: Plate Count Agar; Sabouraud Dextrose Agar; MacConky Broth; Brilliant Green Lactose Broth 2\%; Lactose Broth, EMB, Tryptone water, MRVP Medium and Simmon Citrate Agar; PPEMBA; Baired-Parker's Medium and Brain Heart Infusion; Selenite Cystine Broth, Tetrathionate Brilliant Green Broth, Bismuth Sulphate Agar, Brilliant Green Agar, TSI, LIA, SS Agar and XLD Agar; Listeria Enrichment Broth and Oxford Medium, in addition to the serological kits of Bacto Salmonella $\mathrm{O}$ antiserum.

\subsection{Total aflatoxin analysis}

Twenty five grams of ground samples were prepared and subjected to Veratox kit for total aflatoxin (no. 225902, Neogen, UK), a Competitive Direct-Enzyme Linked Immuno-Sorbant Assay (CD-ELISA) in a microwell format. That allows obtaining exact concentrations in $\mu \mathrm{g} / \mathrm{kg}$ following its individual instructions. The test was read in a microwell reader (Dynatech Laboratories, UK) with Software Version 1.2 to yield optical densities (Lupo et al., 2010).

\subsection{Antimicrobial assay}

2.5.1. Microbial culture

Four strains of bacteria, i.e., Staphylococcus aureus ATCC 6538, Bacillus cereus ATCC 10876, Escherichiae coli ATCC 10536 and Salmonella typhimaurium ATCC 14028, wee used as test microorganisms. 
Comparative Study on the Quality And Antibacterial Activity of Spearmint (Mentha Spicata) Leaves and

\subsubsection{Extract of spearmint oil}

The fresh leaves samples were grinded and subjected to hydrodistillation by Clevenger type apparatus at $100^{\circ} \mathrm{C} / 4 \mathrm{hrs}$ according to Sulieman $\boldsymbol{e t}$ al. (2011). The yellow essential oil was separated and dried by anhydrous sodium disulfate $(0.5 \mathrm{~g})$, filtered through a $0.22 \mu \mathrm{m}$ filter (Millipore, USA), kept in a dark vail at $4^{\circ} \mathrm{C}$ prior further analysis.

\subsubsection{Disk diffusion assay}

The antibacterial activity of $M$. spicata essential oil was examined by disk diffusion assay according to Shahbazi (2015). Separate sets of the filter paper discs (diameter $6 \mathrm{~mm}$; Whatman no. 1) were prepared by impregnated with 10, 20 and $30 \mu \mathrm{l}$ of the essential oil and placed on the surface of Mueller Hinton Agar medium inoculated with the given microorganisms. The plates were incubated $37^{\circ} \mathrm{C}$ overnight and examined for the zone of inhibition. Positive (tetracycline) and negative Dimethyl Sulfoxide Controls were considered in the present test. All experamints were repeated in triplicate.

\subsection{Statistical analysis}

The individual microbial observations were analyzed and expressed in terms of Mean \pm Standard Deviation (SD). T-test for paired comparison was carried out to detect the significant difference $(\mathrm{p}<0.05)$ between the means of spearmint leaves and infusion samples using statistical software (Windows software version 19, 2010, SPSS, Inc, Chicago, IL). The descriptive statistics were carried out to characterize the distribution of the evaluation of the samples (Levin et al., 2013).

\section{Results And Discussion}

The results of microbial analysis including TAVB, molds and yeasts count, spore-forming bacterial count, coliform group, E. coli, B. cereus, Staph. aureus, Salmonella spp., Shigella spp. and Cl. perfringens from 300 samples of spearmint leaves (fresh, loose and packed) and their infusions are described in Table (1). These results show statistical significant microbial difference $(\mathrm{p}<0.05)$ were found between spearmint leaves and infusions. Also, Staph. aureus, Salmonella spp, Shigella spp and $\mathrm{Cl}$. perfringens were not detected in any of the samples, either spearmint leaves or infusions. It was clearly notice that loose samples are exposed to outer atmosphere contained the highest load of TAVB i.e. $5.5 \times 10^{7} \pm 1.4 \times 10^{7} \mathrm{cfu} / \mathrm{g}$, while was $<10 \mathrm{cfu} / \mathrm{g}$ in infusion samples. Packed samples come second with TAVB average $2.7 \times 10^{6} \pm 1.8 \times 10^{6} \mathrm{cfu} / \mathrm{g}$. The fresh samples were the lowest count i.e., $5.7 \times 10^{4} \pm 2.2 \times 10^{4}$ cfu/g. The spore-forming bacterial count ranged within $9 \times 10^{2} \pm 8.7 \times 10^{2} \sim 4.7 \times 10^{4} \pm 2.5 \times 10^{4} \mathrm{cfu} / \mathrm{g}$. The loose samples seem to have more molds and yeasts count $\left(8.7 \times 10^{3} \pm 7.3 \times 10^{3} \mathrm{cfu} / \mathrm{g}\right)$ than packed $\left(6.2 \times 10^{2} \pm 5 \times 10^{2} \mathrm{cfu} / \mathrm{g}\right)$ and fresh $\left(3.5 \times 10^{2} \pm 2.7 \times 10^{2} \mathrm{cfu} / \mathrm{g}\right)$. All of the leaves contained the molds and yeasts count above the tolerable limit $10^{2} \mathrm{cfu} / \mathrm{g}$, which is hazardous. The loose samples showed coliform group counts $\left(2.7 \times 10^{2} \pm 6.0 \times 10^{1} \mathrm{cfu} / \mathrm{g}\right)$ exceeded the acceptable levels. On the other hand, fresh and packed samples were within the acceptable levels. The presence of pathogenic bacteria including E. coli $(18 \sim 28 \%)$ and B. cereus $\left(3.6 \times 10^{1} \pm 0.4 \times 10^{1} \sim 1.1 \times 10^{2} \pm 8.3 \times 10^{1} \mathrm{cfu} / \mathrm{g}\right)$ was also observed. Contamination with E. coli may be a result of either the habitats (proximity of settlements and animals that could contaminate the herbs with urine and feces) or the poor hygiene of the workers (Stevic et al., 2012).

Table 1. The microbiological profile (cfu/g) of spearmint leaves forms and infusions

\begin{tabular}{|c|c|c|c|c|c|c|c|}
\hline Forms & $\begin{array}{l}\text { Type } \\
\text { of } \\
\text { data }\end{array}$ & TAVB & Molds \& Yeasts & $\begin{array}{l}\text { Coliform group } \\
(\mathrm{MPN})^{1}\end{array}$ & E. colt? & B. cereus & $\begin{array}{l}\text { Spore-forming } \\
\text { bacteria }\end{array}$ \\
\hline \multirow[t]{3}{*}{ Fresh leaves } & $\mathrm{L}$ & $5.7 \times 10^{4} \pm 2.2 \times 10^{4}$ & $3.5 \times 10^{2} \pm 2.7 \times 10^{2}$ & $3.2 \times 10^{2}=2.2 \times 10^{2}$ & 18 & $3.6 \times 10^{2}=0.4 \times 10^{1}$ & $9 \times 10^{2} \pm 8.7 \times 10^{2}$ \\
\hline & I & $<10$ & $<10$ & $<3$ & $\mathrm{ND}$ & ND & $<10$ \\
\hline & $p$ & 0 & 0 & 0 & 0.003 & 0 & 0 \\
\hline \multirow[t]{3}{*}{ Loose leaves } & $\mathrm{L}$ & $5.5 \times 10^{7}=1.4 \times 10^{7}$ & $8.7 \times 10^{3}=7.3 \times 10^{3}$ & $2.7 \times 10^{2} \pm 6.0 \times 10^{2}$ & 28 & $1.1 \times 10^{2}=8.3 \times 10^{2}$ & $4.7 \times 10^{4}=2.5 \times 10^{4}$ \\
\hline & I & $<10$ & $<10$ & $<3$ & ND & ND & $<10$ \\
\hline & $p$ & 0 & 0 & 0 & 0 & 0 & 0 \\
\hline \multirow[t]{3}{*}{ packed leaves } & L & $2.7 \times 10^{6}=1.8 \times 10^{6}$ & $6.2 \times 10^{2} \pm 5 \times 10^{2}$ & $7.8 \times 10^{1}=1.3 \times 10^{1}$ & 22 & $7.6 \times 10^{!}=3.1 \times 10^{!}$ & $6.0 \times 10^{3} \pm 4.5 \times 10^{3}$ \\
\hline & I & $<10$ & $<10$ & $<3$ & ND & ND & $<10$ \\
\hline & $p$ & 0 & 0 & 0 & 0 & 0 & 0 \\
\hline
\end{tabular}

L: Mean \pm SD of leaves samples

I: Mean \pm SD of infusion samples

1: count in cells/g

P: Significant (2-tailed)

* No detectable counts of Stap. aureus, Salmonella spp., Shigella spp. and Cl. perfingens were found in any of the samples.
TAVB: Total Aerobic Viable Bacteria

ND: Not Detected

2: count in percent

$-: \mathrm{t}$ cannot be computed because the standard error of the difference is 0 www.iosrjournals.org 
Concerning the Egyptian Standards (ES:2367/2006) require that TAVB should not exceed $10^{4} \mathrm{cfu} / \mathrm{g}$ but anaerobic bacteria, molds and yeasts count, and coliform group below $10^{2}$ and should be free from E. coli, Salmonella spp, Shigella spp and Clostridium spp. In the same context, Debs-Louka et al. (2013) mentioned that samples which sold as loose and exposed to outer atmosphere (sold in an open-air marketplace), are for the majority microbiologically rejected. Handling and packing after drying may result in contamination of processed leaves with microorganisms. Moreover, environmental dust settling on different parts of the plant can potentially carry bacterial and mould spores (Abd El-Aty et al., 2014).

Fig. (1), gives the percentage estimation of the moisture content of the leaves samples under investigation. The moisture content of fresh samples $(85 \%)$ is higher than the dry leave samples either loose $(8.45 \%)$ or packed $(7.37 \%)$.

During this time, if the moisture of the product were to increase to levels allowing spore germination, significant mold growth and possibly mycotoxin production could occur (Stević et al., 2012). The aw of the final product will not support growth of pathogenic bacteria but may enable survival (EFSA, 2013).

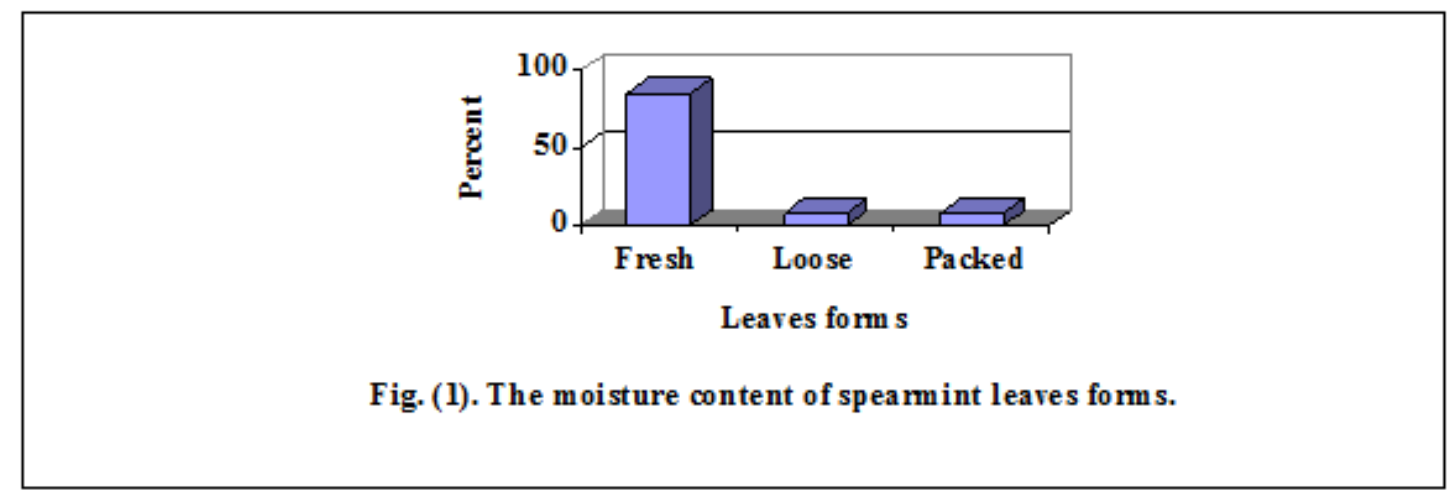

The diameters of the growth inhibition zones are shown in Table (2). The results indicated that spearmint oil has apparent antimicrobial activity against tested pathogenic bacteria. The essential oil $(10,20$ and $30 \mu \mathrm{l})$ exhibited moderate level of antibacterial activity against all test microorganisms. The spearmint oil showed potent antibacterial activity against Staph. aureus, B. cereus, S.typhimurium and E. coli, where the inhibition zones ranged $(6.3 \pm 0.6 \sim 14.7 \pm 0.6 \mathrm{~mm}),(7 \sim 16 \mathrm{~mm}),(4.3 \pm 0.6 \sim 14.3 \pm 0.6 \mathrm{~mm})$ and $(4 \pm 1 \sim 11.7 \pm 0.6 \mathrm{~mm})$, respectively. The highest sensitivity showed by B.cereus $(7,13$ and $16 \mathrm{~mm})$ while E.coli showed the lowest $(4 \pm 1,8.7 \pm 0.6$ and $11.7 \pm 0.6 \mathrm{~mm}$ ) against the previous mentioned doses, respectively.

Table 2. Antibacterial effect of $M$. spicata essential oil against pathogenic bacteria

\begin{tabular}{|l|l|l|l|}
\hline \multirow{2}{*}{ Pathogenic bacteria } & \multicolumn{3}{|l|}{ Dose of M. spicata essential oil } \\
\cline { 2 - 4 } & $\mathbf{1 0} \boldsymbol{\mu l}$ & $\mathbf{2 0} \boldsymbol{\mu l}$ & $\mathbf{3 0} \boldsymbol{\mu l}$ \\
\hline Staph. aureus & $6.3 \pm 0.6$ & $11.3 \pm 0.6$ & $14.7 \pm 0.6$ \\
\hline B. cereus & 7 & 13 & 16 \\
\hline S. typhimurium & $4.3 \pm 0.6$ & 9 & $14.3 \pm 0.6$ \\
\hline E. coli & $4 \pm 1$ & $8.7 \pm 0.6$ & $11.7 \pm 0.6$ \\
\hline
\end{tabular}

This finding agreed with Salim $\boldsymbol{e t}$ al. (2015) in which, microbiological activities of spearmint against Staph. aureus and E. coli resulted in high inhibition. Menthol is the main constituent of mint oil, which is bactericidal against Staph. aureus and E. coli (Balakrishnan, 2015). Znini et al. (2011) suggested that, the antibacterial activity of M. spicata essential oil could be attributed to the presence of carvone and limonene. It has been reported that carvone is one of the most efficient antimicrobial agents of various plants. There were complied with that found by Sulieman et al. (2011). They also concluded that spearmint and spearmint oil can be used as antibacterial, so that they can be used in food preservation. The current results show that Gram positive bacteria were higher in sensitivity response than gram negative bacteria against all the spearmint oil doses. The low susceptibility of Gram-negative bacteria could be attributed to the presence of hydrophobic lipopolysaccharide in their outer membrane which provides protection against different agents (Shahbazi, 2015).

It is evident from the results illustrated in Fig. (2), relative high levels of total aflatoxins were also found in loose $(48.73 \mu \mathrm{g} / \mathrm{kg})$ and packed $(37.32 \mu \mathrm{g} / \mathrm{kg})$ dry samples, while no mean detectable levels were observed in fresh 
leave samples $(<5 \mu \mathrm{g} / \mathrm{kg}$ ). Furthermore, no detectable levels of total aflatoxins were found in any of the infusion samples $(<5 \mu \mathrm{g} / \mathrm{kg})$. Only $20 \%$ of aflatoxins were transferred to hot water. Therefore, the levels of afltoxins in medicinal herbs were considered to safe especially considering the aflatoxin transfer ratio (Lee et al., 2010).

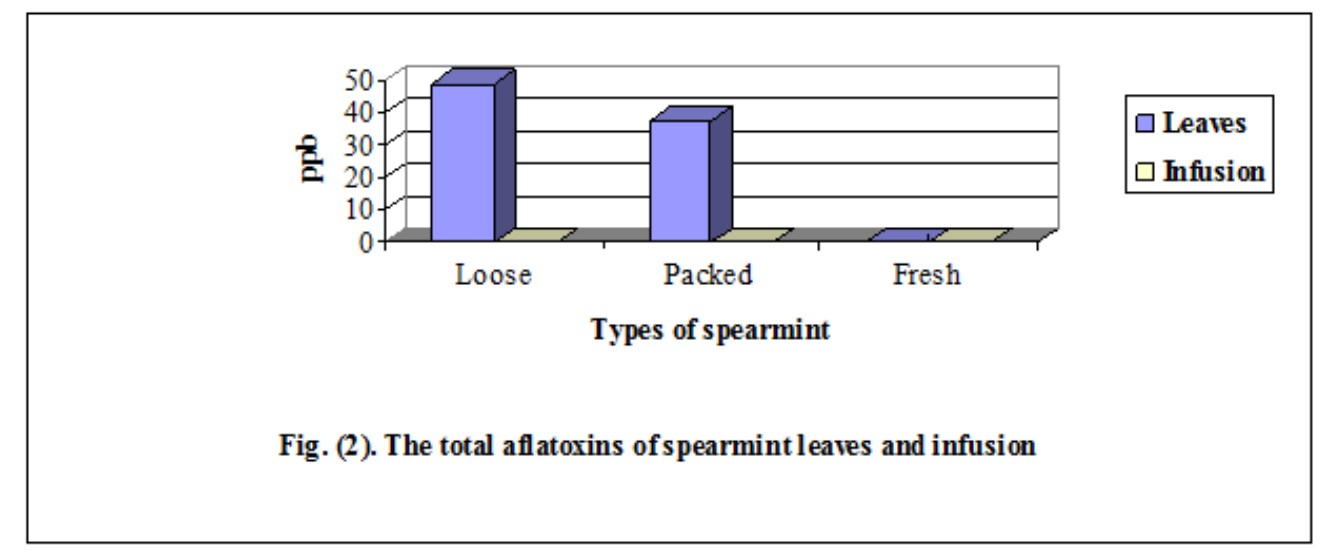

The increase in the consumption of herb medicines has made their use a public health problem due to the potential fungal contamination and the risk of the presence of mycotoxins (Lee et al., 2011). According to Egyptian Standards (ES: 7136/2010) and Commission Regulation (EC: 1881/2006), changes of the concentration of the contaminant caused by dilution process. Liquid samples of the herbal extracts did not register contamination with aflatoxins. On the other hand, $24.0 \%$ of the solid samples were contaminated by aflatoxins (Mukundi, 2015).

\section{Conclusion}

The results of this study indicated high contamination level in dry spearmint leaves rather than fresh leaves and infusions. The maximum microbiological load and total aflatoxin content in dry leaves set by the Egyptian Standards were exceeded in loose and packed samples, while all of the infusion samples were within the acceptable limits. It is therefore important for regulatory monitoring the contaminants in spearmint leaves available in the markets. In addition, post-harvest procedures (drying and storing) should be controlled to minimize fungal growth and thus prevent aflatoxin contamination. The essential oil has remarkable antibacterial activity against common food-borne pathogenic bacteria associated with outbreaks.

\section{References}

Abd El-Aty, A.M.; Choi, J.H.; Rahman, M.; Kim, S.W.; Tosun, A. and Shim, J.H. (2014): Residues and contaminants in tea and tea infusions: a review. Food Additives \& Contaminants: Part A, 31(11): 1794-1804.

Al-Sohaibani, S.; Murugan, K.; Lakshimi, G. and Anandraj, K. (2011): Xerophilic aflatoxigenic black tea fungi and their inhibition by Elettaria cardamomum and Syzygium aromaticum extracts. Saudi J. Biol. Sci., 18: 387-394.

AOAC (2006): Official method of analysis of association of official analytical chemist international. In: Horwitz, W., $18^{\text {th }}$ ed. AOAC Press, Arlington, VA, USA, No. 934-01.

Balakrihnan, A. (2015): Therapeutic uses of peppermint - A review. J. Pharm. Sci. \& Res., 7(7): 474-476.

Chotchoungchatchai, S.; Saralamp, P.; Jenjittikul, T.; Pornsiripongse, S. and Prathanturarug, S. (2012): Medicinal plants used with Thai Traditional Medicine in modern healthcare services: a case study in Kabchoeng Hospital, Surin Province, Thailand. J Ethnopharmacol., 7;141(1):193-205.

Commission Regulation (EC: 1881/2006): Setting maxium levels for certain contaminants in foodstuffs. Off. J. Eur. Union, L364/5.

Debs-Louka, E.; El Zouki, J. and Dabboussi, F. (2013): Assessment of the Microbiological Quality and Safety of Common Spices and Herbs Sold in Lebanon. J. Fd. Nutr. Disor., 2(4): 1-6.

Egyptian Organization for Standardization and Quality (ES: 2006): Dried mint. (No. 2367).

Egyptian Organization for Standardization and Quality (ES: 2010): Maximum levels for certain contaminations in foodstuffs. (No. 7136).

European Food Safety Authority (EFSA, 2013): Scientific Opinion on the risk posed by pathogens in food of non-animal origin. Part 1 (outbreak data analysis and risk ranking of food/pathogen combinations). EFSA Journal, 11(1):3025.

Harrigan, W.F. (1998): Laboratory Methods in Food Microbiology. $3^{\text {rd }}$ ed. Academic Press Ltd. Pp: 164-210.

Helal, G.A.; Sarhan, M.M.; Abu-Shahla, A.N.K. and Abou El-Khair, E.K. (2006): Antimicrobial activity of some essential oils against microorganisms deteriorating fruit juices. Microbiology, 34(4): 219-229.

Hell, K.; Fandohan, P.; Bandyopadhyay, R.; Cardwell, K. and Kiewnick, S. (2008): Pre- and post-harvest management of aflatoxin in maize: an African perspective. In: Leslie, J.F.; Bandyopadhyay, R. and Visconti, A.C. (eds.) Mycotoxins: Detection methods, management, public health and agricultural trade. ABI Publishing, Wallingford, UK, pp. 210-219.

ICMSF (1978): Microorganisms in Food 1. Their significance and methods of Enumeration ( ${ }^{\text {nd }}$ ed.), Toronto, University of Toronto Press, pp: 107-273. 
Comparative Study on the Quality And Antibacterial Activity of Spearmint (Mentha Spicata) Leaves and

ICMSF (1996): Microorganisms in Food 5. Application of the Hazard Analysis Critical Control Point (HACCP) System to Ensure Microbiological Safety and Quality (in Portuguesee) Livraria Varela Ltda, Sao Paulo, pp: 20-299.

International Standard (ISO, 2013): Microbiology of the food chain-Horizontal method for the enumeration of microorganisms. Part1: colony count at $30^{\circ} \mathrm{C}$ by the pour plate technique. SGS SA. (no. 4833-1).

Karicheri, R. and Antony, B. (2016): Antibacterial and antibiofilm activities of peppermint (Mentha piperita Linn) and Menthol ment (Mentha arvensis Linn) essential oil on Aggregatibacter actinomycetemcomitans isolated from orodental infections. EJPMR, 3(7): 577-581.

Lee, S.; Kim, Y.; Kim, N.; Jung, H.; Jung, S.; Kim, H.; Kim, K.; and Han, K. (2011): A study on aflatoxins analysis in the herb medicines. J. Fd. Hyg. Safety, 26(4): 424-434.

Lee, S.; Kim, Y.; Yoon, Y.; Park, A.; Shin, Y.; Kim, H.; KimY. and Choi, B. (2010): Monitoring of aflatoxin in medicinal herbs. Korean J. Med. Crop Sci., 18(5): 338-344.

Levin, J.; Fox, J.A. and Forde, D.R. (2013): An SPSS 19 companion book to elementary statistics for social scientists, $11^{\text {th }}$ ed. Published by Allyn and Bacon, p. 63-105.

Lupo, A.; Roebuck, C.; Dutcher, M,; Kennedy, J. and Abouzied, M. (2010): Validation study of a rapid ELISA for detection of aflatoxin in corn. J. AOAC Int., 93(2): 587-599.

Mandana, B.; Russly, A.R.; Ali, G. and Farah, S.T. (2011): Antioxidant activity of spearmint (Mentha spicata L.) leaves extracts by Supercritical Carbon Dioxide (SC-CO2) extraction. Int. Fd. Res. J., 18: 543-547.

Mukundi, J.W. (2015): Bacteria, aflatoxins and floride levels in locally processed herbal medicines from Nairobi Country, Kenya. MSc. Thesis Science in Pharmacology and Toxicology, Faculty of Veterinary Medicine, Nairobi Univ., Kenya.

Pramila, D.M.; Xavier, R.; Marimuthu, K.; Kathiresan, S.; Khoo, M.L.; Senthilkumar, M.; Sathya, K. and Sreeramanan, S. (2012): Phytochemical analysis and antimicrobial potential of methanolic leaf extract of peppermint (Mentha piperita: Lamiaceae). J. Med. Plants Res., 6(2): 331-335.

Salim, E.A.; Yagi, S. and Elyass, H.M.M. (2015): Histology, photochemistry and microbiologyof spearmint [Mentha spicata L. (Labiaceae)]. J. Forst Products \& Industries, 4(3): 107-113.

Santini, A.; Raiola, A.; Meca, G. and Ritieni, A. (2015): Aflatoxins, Ochratoxins, Trichothecenes, Patulin, Fumonisins and Beauvericin in Finished Products for Human Consumption. J. Clin. Toxicol., 5(4): 265-276.

Santos, L.; Marin, S.; Sanchis, V. and Ramos, A.J. (2013): Mycotoxin in Medicinal/Aromatic Herbs - a Review. Boletín Latinoamericano y del Caribe de Plantas Medicinales y Aromáticas 12 (2): $119-142$.

Shahbazi, Y. (2015): Chemical composition and in vitro antibacterial activity of Mentha spicata essential oil against common food-borne pathogenic bacteria. J. Pathogens, Published online PMCID: PMC4553199.

Soriano, J.M.; Rico, H.; Moltó, J.C. and Mañes, J. (2002): Effect of introduction of HACCP on the microbiological quality of some restaurant meals. Food Cont., 13: 253-261.

Stević, T.; Pavlović, S.; Stanković, S. and Šavikin, K. (2012): Pathogenic microorganisms of medical herbal drugs. Arch. Biol. Sci., 64(1):4958.

Sulieman, A.E.; Abdelrahman, S.E. and Abdel Rahim, A.M. (2011): Phytochemical analysis of local spearmint (Mentha spicata) leaves and detection of the antimicrobial activity of its oil. J. Microbiol. Res., 1(1): 1-4.

Znini, M.; Bouklah, M. and Majidi, L. (2011): Chemical composition and inhibitory effect of Mentha spicata essential oil on the corrosion of steel in molar hydrochloric acid. Int. J. Electrochemical Sci., 6(3): 691-704.

$$
\begin{aligned}
& \text { دراسه مقارنه على جودة أوراق ومشروب النعناع وتأثثيره المضاد للبكتريا } \\
& \text { عماد عاطف حلمى جرجس } \\
& \text { قسم صحة الطعام ـ الدعهد القومى للتغذيه ـ العيئه العامه للمستشفيات و المعاهد التعليمبه - جمهورية مصر العربيه }
\end{aligned}
$$

الملخص العربي: تهدف هذه الدراسه إلى مقارنة السلامة الميكروبيه لأوراق ومشروب النعناع وتأثبير ها المضاد لبعض البكتريا المدرضه. تمثل 300

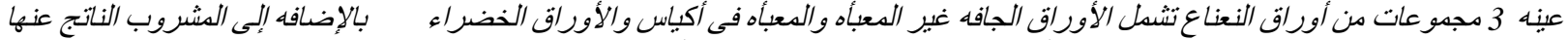

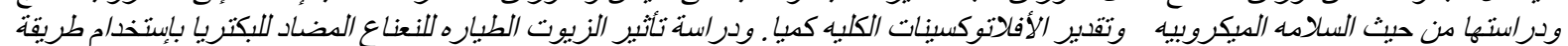

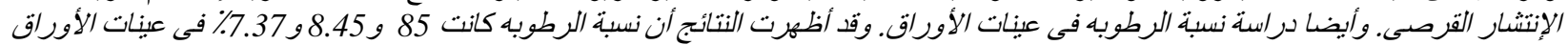

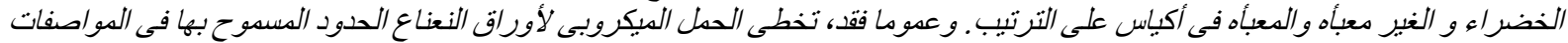

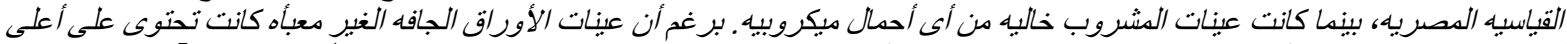

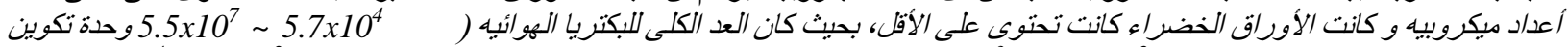

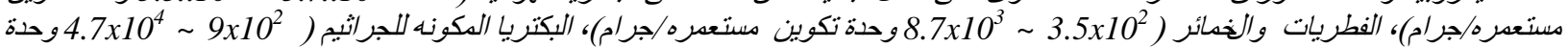

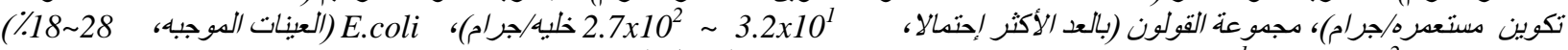

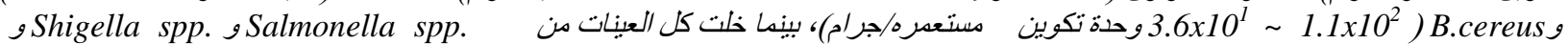

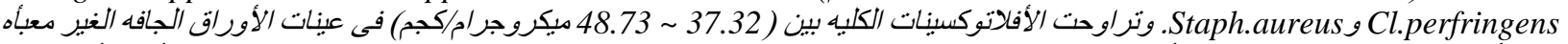

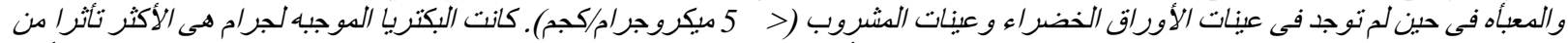

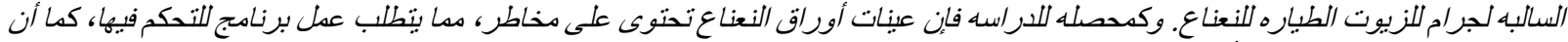

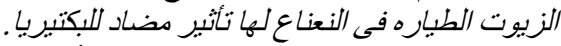

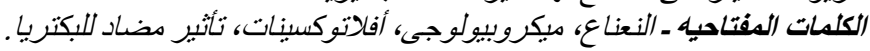

